\title{
Piotr Świercz
}

Akademia Ignatianum w Krakowie

(D) https://orcid.org/0000-0002-6290-879X

\section{The Allegory of the Cave and Plato's Epistemology of Politics}

\section{Mit jaskini i Platońska epistemologia polityki}

\begin{abstract}
Abstrakt: Celem artykułu jest analiza Platońskiej epistemologii polityki w świetle VII księgi Państwa, przedstawiającej mit jaskini. Tytułowe zagadnienie jest ukazane w kontekście werytatywnej interpretacji ontologii greckiej (w nawiązaniu do dzieł Charlesa Kahn'a), a także na tle polemiki Platona z sofistyką (Protagoras i Gorgiasz) wraz z odniesieniami do źródeł Platońskich inspiracji — Eleaci i pitagorejczycy. W trakcie analiz zaproponowane zostaną hipotezy dotyczące pewnych aspektów mitu jaskini (e.g. status ognia), jak i zaprezentowana zostanie interpretacja Platońskiego projektu polityczno-filozoficznego.
\end{abstract}

Słowa klucze: Platon, mit jaskini, epistemologia, ontologia werytatywna, filozofia polityki

The goal of this text is to analyze Plato's epistemology of politics. In other words, it is a reconstruction, or more precisely, an indication of a possible interpretative model of Plato's political reflection. The necessary starting point for achieving this goal is to show the context of Plato's thought. This contextual analysis, which is necessarily limited to a very synthetic sketch, will be divided into two parts. (1) I will point to the inseparability of epistemology and ontology in Greek pre-Platonic (and Platonic) reflection; this inseparability, in turn, leads to a particular version of ontology, which I call veritative ontology to differentiate it from existential ontology. (2) I will outline the political and legal reflection of sophistry, which is the 
main reference point for Plato, as it is overcoming sophistry which, in my opinion, was Plato's main goal. In this context, it will also be necessary to refer to the main theses of Pythagorean and Eleatic reflection, whose criticism (especially Eleatism) was, on the one hand, an integral part of sophistry, and on the other - an important source of inspiration for Plato.

I consider it necessary to emphasize that my intention is, as I emphasized above, to indicate a possible interpretative model, not to present an exhaustive elaboration of this topic. Many issues will be treated very synthetically. A full analysis of the issue would require a monograph, perhaps more than one. However, my interpretation may serve as a starting point for further research.

\section{The context of Plato's political reflection}

\section{Veritative ontology}

The starting point for the concept of veritative ontology is a reference to the research of Charles H. Kahn and his book The Verb "Be" in Ancient Greek.

I'd like to start with a very short summary of Kahn's analysis of the meaning of einai in ancient Greek. The main thesis of Kahn's article The Greek Verb "To Be" and the Concept of Being, ${ }^{1}$ recently elaborated in his famous book, is that "the Greeks did not have our notion of existence." Instead, as Kahn convincingly proves, "for the philosophical usage of the verb, the most fundamental value of einai when used alone (without predicates) is [...] 'to be so,' 'to be the case,' or 'to be true."'3 Very important for the purpose of my thesis are Kahn's remarks about the durative aspect of einai. The verb einai has no aorist and no perfect forms. Kahn pointed out some philosophical consequences of this: "what is the philosophic significance of this morpho-semantic fact? I think it may help us to understand (1) the Greek notion of eternity as a stable present, an untroubled state of

1 C.H. KaHn: The Greek Verb "To Be" and the Concept of Being. "Foundations of Language” 1966, vol. 2, pp. 245-265.

2 Ibid., p. 248.

3 Ibid., p. 250. 
duration, (2) the classical antithesis of Being and Becoming, and (3) the incommensurability already noted between the Greek concept of being and the modern-medieval notion of existence."4

The veritative meaning of einai allows us not only to make translational corrections to Greek philosophical texts and to indicate an alternative to the existential conception of ontology; the veritative meaning of einai also allows us to look at all of Greek philosophy from a completely new perspective. Its object, its aim would not be to determine what exists and what does not exist. Rather, it would be to gain an understanding of how the kosmos functions, an understanding of its laws. And understanding the kosmos, in itself, would connect in an inextricable way the ontological aspect with the epistemological aspect. In other words: we are talking about understanding "understanding" as the only possible way of non-dogmatic philosophizing.

Veritative ontology can be most precisely characterized on the example of Eleatian thought. Parmenides plays a special role in the history of philosophy: he was the first philosopher to introduce the terms to on, to eon, to ouk on, to me on. How the source meanings of these concepts in the philosophy of Parmenides are understood affects our understanding of the whole of post-Eleatic Greek philosophy. Here, I would like to concentrate only on the meaning and relations connecting four concepts: being, non-being, truth, and opinion. ${ }^{5}$ For obvious reasons, the analysis presented here will be very concise and synthetic.

In his treatise Peri Physeos, Parmenides writes about two ways of cognition: the way of Truth, whose object is being, and the way of opinion,

${ }^{4}$ Ibid., p. 255.

5 For clarity, it is necessary to emphasize at the start that I am a strong advocate of the two-way interpretation of Parmenides's poem Peri Physeos, which distinguishes the way of Truth and way of opinions. I reject, as completely inconceivable, those interpretations that distinguish a third way - the way of falsehood. The reasons for my position will become clear after an analysis of the concepts of being, non-being, truth, and opinion, but I will briefly indicate why accepting a "way of falsehood" is absurd. If truth corresponds to being, and opinion to non-being, we are faced with the fundamental question of what could correspond to falsehood. Being and non-being seem to fill up the entire admissible spectrum. If that is the case, then the way of falsehood is "empty" - in other words, it is not there at all! In reference to doubts that may arise about whether it is justified to connect opinion with non-being, since both Parmenides (fr. B6) and Plato (Respublica, 478e) indicate that opinion corresponds to a mixture of being and non-being: this is an intentional simplification on my part. Presuming that a) opinion is a mixture of being and non-being, b) opinion is not truth, and c) being corresponds to truth, we must conclude that opinion is different from truth due to its admixture of non-being. Thus opinion corresponds to non-being. I consider this mixture a form of relative non-being, because (e.g. in the light of Zeno's paradoxes) it is impossible to even imagine a form of knowledge corresponding to absolute non-being. 
whose object is non-being. What are being and non-being? If we accept an existential understanding, the whole line of argument loses its significance. How could there be a way of opinion referring to what does not exist? The only alternative to the existential interpretation, both in light of the fragments of Parmenides's text and in light of the principles of rational analysis, is the acceptance of a non-existential understanding of the concepts of "being" and "non-being." Being (to eon) is as follows:

1. non-born and indestructible;

2. eternal;

3. immutable;

4. indivisible and complete;

5. full and non-gradational;

6. absolute and identical;

7. necessary and connected to justice and righteousness;

8. authoritative;

9. unified. ${ }^{6}$

In consequence, non-being does not refer to what is non-existent, but to what is born and perishable, temporal, mutable, divisible and incomplete, gradational, relative and non-identical, unnecessary and unconnected with justice and righteousness, unauthoritative and plural. Non-being cannot be grasped by true cognition, only by "probable" cognition. ${ }^{7}$ Neither the concept of "being," nor the ontology at its source are existential in nature; rather, they are veritative-epistemological.

What are the political and legal consequences of the veritative standpoint? The matter is undoubtedly complicated. The main problem lies in establishing the relationship between being and non-being. Are they levels of reality that are isolated from one another or are they somehow connected? It seems that two possibilities are justified here. The first is recognizing that the levels of being - truth and non-being-opinion are completely separate from one another. Consequently, knowing the truth-being would be useless at the level of non-being-opinion. The second possibility is that these two levels are connected, but it is a one-way relationship - that is, only being - truth affects non-being - opinion, not the other way around. In this

6 D. KuboK: Prawda i mniemania. Studium filozofii Parmenidesa z Elei. Katowice 2004, pp. 444-445.

7 The question arises whether we see a similar distinction between certain knowledge and probable knowledge in Pythagorean philosophy, though such a distinction is not made expressis verbis. Of course, this question is open and debatable. However, I think that in Pythagorean philosophy, the status of certain knowledge can be ascribed to mathematics. Knowledge of entities that can be grasped by the senses would belong to the category of probable knowledge. 
case, knowing the truth-being would be the basis for probabilistic knowledge of the sphere of non-being - opinion, although the "probabilistic truth" concerning non-being - opinion would not be identical with truth-being, but would merely constitute its approximation.

The second problem regarding the political and legal consequences of veritative ontology concerns the classification of the political and legal aspect itself: does it belong to the sphere of being - truth or non-beingopinion? Taking into consideration the features of both orders presented by Parmenides, it seems reasonable to attribute political and legal reality to the sphere of non-being-opinion. However, the matter is more complicated. After all, in the sphere of being - truth we can create rational constructs of law and of the state. While everyday political and legal activity, with its multiplicity and volatility, certainly belongs to the sphere of non-beingopinion, it seems crucial here to settle the problem of the relationship between the sphere of being - truth and non-being-opinion. If they are isolated, the matter is closed - the political and legal aspect belongs to the sphere of non-being - opinion. However, if we accept the alternative I have indicated - that the sphere of being - truth affects the sphere of non-being opinion - things get much more complicated. The political and legal aspect, although in our daily activities belonging to the sphere of non-beingopinion, would be (or at least could be) somehow rooted in the sphere of being - truth. The key question is: what does this rootedness consist in? Let us put the problem rather naively - does the rooting concern only some of the most general laws of reason, such as mathematical and logical rules, or more specific "political and legal" threads, such as "true" justice, the cognition of which is a prerequisite for bringing about the best possible "probabilistic justice" in the sphere of non-being-opinion, or even a "true" political system that would constitute a model for all regimes implemented in the sphere of non-being-opinion? At the moment, I will leave this issue open. I will return to it while analyzing Plato's conception. 


\section{Sophist political and legal reflection}

In this article I will focus only on two representatives of the so-called "old sophistry," namely Protagoras of Abdera and Gorgias of Leontini. Before I move on to political and legal issues, I will outline the ontological and epistemological foundations of sophistry, without which it is impossible to understand the political and legal aspect. My analysis will be based on two issues: Protagoras's principle of anthropos metron (homo mensura) and the theses of Gorgias's treatise Peri tou me ontos e periphyseos ["On NonBeing or on Nature"]. At this point, I will leave aside the conception of justice from the dialogue Protagoras. I will cite it in the last part of this text.

8 There is a very rich secondary literature devoted to "old sophistry" (Protagoras and Gorgias) available. In Polish, the most important are studies authored by J. GAJDA-KRYNICKA (Sofiści. Warszawa 1989; Przedplatońskie koncepcje prawdy. Gorgiasz z Leontinoi. In: Prawda, język, szczęście. Studia z filozofii starożytnej (II). Ed. J. GaJdA, A. Orzechowski, D. Dembińska-Siury. Wrocław 1992, pp. 15-54.) and Z. NercZuk (Sztuka a prawda. Problem sztuki w dyskusji między Gorgiaszem a Platonem. Wrocław 2002; Miara jest każdy z nas. Projekt zwolenników zmienności rzeczy w platońskim Teajtecie na tle myśli sofistycznej. Toruń 2009; Parafraza gorgiańskiego traktatu „O niebycie” $w$ wersji Sekstusa Empiryka. In: Sapereaude. Ksiega pamiatkowa ofiarowana profesorowi dr. hab. Marianowi Szarmachowi z okazji 65 rocznicy urodzin. Ed. I. MıкOŁAJCZyK. Toruń 2004, pp. 185-201; Traktat „O niebycie” Gorgiasza z Leontinoi. "Przegląd Filozoficzny Nowa Seria" 1997 vol. 3, no. 23, pp. 79-94; Wokót sofistyki. Toruń 2016). Major studies from world literature include: G. CAlogero: Studisull' Eleatismo. Roma 1932; B. Cassin: Si Parmenide. Le traite anonyme De Melisso Xenophane Gorgia. Edition critique et commentaire. Lille 1980; R.N. GAINES: Knowledge and Discourse in Gorgias's "On the Non-Existent or On Nature." "Philosophy and Rhetoric" 1997 vol. 30, no. 1, pp. 1-12; O. Gigon: Gorgias "Uber das Nichtsein." "Hermes" 1936, vol. 71, pp. 186213; H. Gomperz: Sophistik und Rhetorik. Leipzig 1912; G.B. Kerferd: The First Greek Sophists. "The Classical Review" Apr. 1950 vol. 64/1, pp. 8-10; G.B. Kerferd: The Sophistic Movement. Cambridge 1981; G.B. Kerferd, Ed.: The Sophists and Their Legacy (Hermes Einzelschriften, 44.). Wiesbaden 1981; A. Levi: The Ethical and Social Thought of Protagoras. "Mind" 1940, no. 40, pp. 284-302; A. Long: Refutation and Relativism in Theaetetus 161-171. "Phronesis" vol. XLIX/1, pp. 24-40. M. Mendelson: Many Sides: A Protagorean Approach to the Theory, Practice and Pedagogy of Argument. DordrechtBoston-London 2002; M. Nussbaum: Sophistry about Conventions. "New Literary History" Autumn 1985, vol. 17, no. 1 Philosophy of Science and Literary Theory, pp. 129139; E. SchiAPPA: Interpreting Gorgias's "Being” in "On Not-Being or On Nature." "Philosophy and Rhetoric" 1997, vol. 30, no. 1, pp. 13-30; E. Schiappa: Protagoras and Logos: A Study in Greek Philosophy and Rhetoric. Columbia (South Carolina) 2003; F.D. Walters: Gorgias as Philosopher of Being: Epistemic Foundationalism in Sophistic Thought. "Philosophy and Rhetoric" 1994, vol. 27, no. 2, pp. 143-155. 
I will start in an unusual way, not from Protagoras, but from a very brief discussion of the theses in Gorgias's treatise.

Two extant ancient texts summarize the On Non-Being. One is authored by Sextus Empiricus, ${ }^{9}$ the other is written by an anonymous author, previously identified with Aristotle. ${ }^{10}$ Both versions differ in their details, which, however, I will skip in this analysis, focusing rather on the most general issues.

Gorgias's treatise is read in the context of a polemic with Eleatism. ${ }^{11}$ From this perspective, it would be a critique of the possibility of knowing absolute truth. Given this interpretation, the three theses of the treatise should be read as follows:

1. there is no absolute truth;

2. even if there was absolute truth, it would not be knowable by the human being;

3. even if there was absolute truth and it would be knowable by a human being, it would not be transferrable to other human beings.

While the second and third theses are obviously epistemological, the first seems to be an ontological thesis. Closer analysis, however, strongly indicates its veritative, not existential nature. In his justification, Gorgias points to the equal strength of the various accounts of being - truth. ${ }^{12}$ It is impossible to decide which of the mutually exclusive ways of cognition is right. Consequently, the adoption of any of them is unfounded. I would venture the following hypothesis: the essence of Gorgias's veritativeontological argument against being - truth lies in showing the impossibility of formulating a non-contradictory and comprehensive model of beingtruth, a model that would either synthesize and reconcile all other possible models, or would indisputably refute these models while itself - alone remaining irrefutable.

The second thesis seems to indicate the incompatibility of human cognitive capabilities with the absolute. Man can create in his mind a conception of the absolute (though, as I suggested above, such a conception would be inconsistent), but human cognition, which is always contextual and relative, cannot grasp the absolute as absolute, even if it did come across that which is absolute. In other words, in the process of cognition one could only grasp the absolute as relative, because we do not possess absolute cognitive tools.

9 Sextus Empiricus: Adv. Math., VII, 65,1-87, 5.

10 De Melisso, Xenophane, Gorgia, 979a11-980b21.

11 See e.g. Z. Nerczuk: Wokól sofistyki, pp. 115-154; G. Calogero: Studi sull' Eleatismo; O. Gigon: Gorgias “Uber das Nichtsein,” pp. 186-213.

${ }_{12}$ Adv. Math., VII 66,1-76, 6. 
Human cognitive abilities do not allow us to distinguish between the relative and the absolute, even if there is such a thing as absolute being - truth. ${ }^{13}$

The third thesis concerns the possibility of relaying possible knowledge concerning the absolute. Gorgias again indicates the incompatibility of human instruments of communication - language, with what is absolute. No one is able to relay knowledge to others - only words. All messages, therefore, will be contextual and relative. Therefore, it is not possible to convey knowledge about the absolute by means of human communication, i.e. by means of language, even if there was an absolute, and even if someone managed to grasp it through cognition. ${ }^{14}$

What are the social, political, and legal consequences of Gorgias's conception? His rejection of the possibility of grasping being-absolute truth sheds new light on the issue of political decisions, and especially law making. From the Eleatic dualism of truth-opinions only opinions remain. What is more, even if someone achieved the knowledge of absolute truth, then in the social context (the third thesis of the Treatise on Non-Being) this absolute truth will be nothing more than another opinion that in terms of truth does not possess a privileged status over other opinions. Absolute truth as a criterion for political and legal activity must be rejected, because anyone's claim to possessing this truth will always be unfounded.

In the light of Gorgias's treatise, the Eleatic problem of the relationship between the realms of being - truth and non-being-opinions is resolved as follows:

1. There is only one sphere of non-being-opinions.

2. Even if there were two spheres, human cognitive capabilities make it impossible to distinguish between them, because man cannot grasp the sphere of being-truth.

3. Even if there were two spheres and the human individual could distinguish them and get to know the sphere of being-truth, it would be impossible to convey this knowledge to others.

4. Ergo, at the level of socio-political life we are forced to limit ourselves to the sphere of non-being-opinions.

The most important source of information about Protagoras's best known conception is Plato's dialogue Theaetetus (and also Cratylus). ${ }^{15}$ The second most frequently cited source - Sextus Empiricus's texts ${ }^{16}$ - is most likely dependent on Plato's message.

13 Adv. Math., VII 77,1-82, 4.

14 Adv. Math., VII 83,1-87, 1.

15 Plato: Theaetetus, 152A2-4, 166D1-4; Cratylus, 385E6-386A4.

16 Sextus Empiricus: Adversus Mathematicos, book VII, sections and lines 60, 7-61, 2; Pyrrhoniae hypotyposes, book I, section 216, lines $1-7$. 
The anthroposmetron principle, as the founder of the Academy introduces it in his dialogue, is based on the assumption that all human cognition is initiated by sensual impressions. However, each individual differs from others in the way s/he senses reality. Simply put - the senses of each of us are different from those of other people. Consequently, there are as many ways of sensually grasping reality as there are individuals. ${ }^{17}$ We can even venture the hypothesis that each individual, because of the specific state in which s/ he is in the moment of the sensory experience, "receives" reality in different ways. This means that there are more possible descriptions of reality based on sensory experience than there are human individuals - each of an individual's experiences forms the basis for a different description and interpretation of reality. ${ }^{18}$ In this way, Protagoras refutes the possibility of knowing the absolute truth - it is impossible to point to the criterion of such truth. Only opinions or relative truths are available to man. They are true only in a specific context characterized by specific states of the perceiving subject. ${ }^{19}$ A point of contention is the interpretation of Sextus Empiricus, who suggests that Protagoras's position is not limited to epistemology, but also results from ontological assumptions. Sextus states that Protagoras accepts that reality itself is changeable. This would mean that the reasons for the lack of a criterion of absolute truth lie not only in the relativity of human cognition, but also in the very nature of things. ${ }^{20}$ However, is Protagoras's thesis on the changeability of reality really relevant in the context of the criterion of absolute truth?

The permanent changeability of reality and its relationality undoubtedly make it difficult to grasp the possible rules and principles governing that reality. However, they do not render such samples senseless and do not prejudge the impossibility of achieving this goal. For changeability to decide about the impossibility of grasping the absolute truth, it would have to be a special type of changeability devoid of any fixed characteristics. In other words, the world would have to be chaos. However, is the concept of "changeability" appropriate for describing chaos? Does Protagoras say anywhere that the world is chaos? It seems that not only do we not find any premises to defend such an interpretation, but even on the contrary - we can point to threads in Protagoras's reasoning that seem to negate it.

In the Apology of Protagoras from Theaetetus, Plato points to the analogy between the physician of the body and the physician of the soul,

17 Plato: Theaetetus, 166el-4, 167a7-167b1.

18 Plato: Theaetetus, 166D1-4.

19 Sextus Empiricus: Adv. Math., VII, 61, 5-64, 5; SeXtus Empiricus: Pyrrhoniae hypotyposes, I, 218, 4-219, 3.

20 Sextus Empiricus: Pyrrhoniae hypotyposes, I, 217, 4-218, 4; 219, 7-10. 
i.e. the sage in Protagoras's thought. What underlies the activities of both types of doctors is the belief in the possibility of comparing the states of the body and soul (mind) from the perspective of their usefulness. ${ }^{21}$ Even if we assume that specifying what is more or less useful is sensitive to the circumstances and to the context (that is, what is more useful in a given context may be less useful in another - the changeability would therefore also apply to the content of usefulness), the very fact that usefulness is accepted by Protagoras as a kind of guide in the process of choosing between various options seems incompatible with chaos.

Usefulness is also the most important criterion for assessing political action and the value of legal arrangements. It is not absolute truth, which, if it exists at all, is elusive for people, but the principle of usefulness that is the criterion of wisdom. The wise man can recognize what will be more useful to the individual or the state in the given circumstances. He will also be able to convince both the individual and the state to abandon less useful (though no less true) opinions or laws in favor of more useful (though not more true) opinions and laws - this is how the particular "psychiatric" role of the sophistic sage is expressed. ${ }^{22}$

To sum up the conceptions of sophistry (of Protagoras and Gorgias), it should be emphasized that the foundation is a veritative-epistemological position, according to which the tools of human cognition are incompatible with being - absolute truth. It is impossible for humans to grasp the absolute. Absolute truth cannot, therefore, be the foundation of human actions, either those of the individual or the community.

All human opinions, based on individual sensory experience, are equally "true" - but this "truthfulness" is always relative and contextual. No human opinion can legitimately claim to be "more real." This necessarily leads to a particular version of the social contract. However, in the sophistic version of the social contract, the status of a wise man is distinguished, understood not as possessing absolute truth, but as recognizing what is more useful in a given context and able to convince other individuals and citizens of the poleis of this.

\footnotetext{
21 Plato: Theaetetus, 166e4-167a6.

22 Plato: Theaetetus, 167b1-2; 167b5-167c4.
} 


\section{Plato's criticism of sophistry}

There is a huge literature devoted to the subject of Platonic criticism of sophistry. My goal here is not even a very synthetic attempt to refer to all the threads concerning this criticism. I will focus only on the most important aspects, from the perspective of this article's purpose, such as the question of the criterion of absolute truth and the issue of how usefulness is understood and validated in sophistic reflection.

Absolute truth and the ability to grasp it in human cognition were the necessary conditions for the legitimacy of philosophy. In turn, the sociopolitical importance of philosophy results from the possibility of the interpersonal communication of absolute truth, its translatability into human language, and its applicability in legal regulations and the political decisionmaking process. Sophistry, striking a blow at all three aspects (the absolute truth itself, the ability to learn about it, and the ability to effectively communicate it), undermined the importance of philosophy and its role in social and political life. Although it retained the concept of "wisdom," it gave it a completely different meaning. The rehabilitation of the pre-sophistic understanding of philosophy is a key element of Plato's reflection.

As I indicated above, the starting point of the sophists' conception is the assumption that all human cognition is initiated by a sensory grasp of reality. This must necessarily lead to relativism and the equal strength of all opinions. A defense of the epistemologically privileged status of beingtruth necessarily requires overcoming the aporia indicated by the sophists. The only way to achieve this is to make human cognition at least in part independent of sensual impressions.

Consequently, Plato's epistemology is focused on mental cognition noesis, which is contrasted with sensual cognition - aisthesis. ${ }^{23}$ In the Republic, Plato indicates two levels of mental cognition. The first is $d i$ anoia - mathematical cognition, which is mental cognition "bordering on" sensual cognition. The point is that the essence of dianoia is mental cognition, but sensual perception serves as a kind of epistemological help. The best illustrations in this case are geometry and stereometry. In themselves, these are ways of mental cognition, but illustrations and measurements facilitate understanding - they are intermediate stages in the teaching process, which aims to develop the skill of pure thinking. Hence the description of mathematical entities as intermediate entities - they are noetic, but still possible

23 Plato: Republic, VI, 508b12-511e5. 
to illustrate and thus to grasp sensually. Although this sensory grasp does not encompass the essence of mathematical entities, it is nevertheless necessary and helpful especially at the introductory stages of the noetic method. ${ }^{24}$

The second level is the purest form of noesis. ${ }^{25}$ It is completely and exclusively mental cognition, entirely "free" from sensual connections. Noesis is the cognition of ideas, perfect numbers, and finally principles - henagathon and aoristosdyas. ${ }^{26}$ Their status is different from what is sensually graspable (the sphere of aisthesis), as well as from what is sensually illustratable (the sphere of dianoia).

The problem arises when we think about the way in which we arrive at mental cognition. Showing the full path to cognition in Book VI of the Republic, which he then illustrates using the Myth (Allegory) of the Cave in Book VII, Plato begins with aisthesis (eikasia and pistis) to then - through dianoia - reach noesis. One may get the impression that each higher level results from a lower level. Does this mean that noesis and dianoia are rooted in aisthesis? In other words, is abstraction the basic cognitive instrument realized at the noetic level?

It depends on how you define "abstraction" and "abstracting." Abstractio understood as "detachment" suggests a procedure that is best illustrated using simple arithmetic. We have 2 horses (2h), 2 sheep (2p), and 2 dogs (2k). How many animals ( $\mathrm{z}$ ) do we have in total? Of course, $2 \mathrm{~h}+2 \mathrm{p}+2 \mathrm{k}=6 \mathrm{z}$. We abstract the numbers from the letters and get an abstract formula $2+2+2=6$. Can this reasoning also be applied to geometry and stereometry? Certainly not. Sensory experience does not provide us with any data concerning geometric and stereometric entities. In aisthesis, we do not encounter anything that would be a straight line, triangle, cube, etc. We cannot, therefore, abstract geometric and stereometric entities from what we have grasped in sensory experience. The path to geometric and stereometric entities (and even more so to ideas, ideal numbers and principles) requires the process of idealization. The essence of idealization lies in the mind's ability to create a reality (or realities) alternative to the one about which sensual experience informs us. Idealization is therefore not an abstraction in the simple sense illustrated above. Of course, as is always the case with human word games, we can define "idealization" as "idealizational abstraction" (as opposed to "non-idealizational abstraction" or "ordinary

24 Plato: Republic, VI, 510b4-511b2.

25 Plato: Republic, VI, 511b3-511c2.

26 The secondary literature concerning Plato's teaching on principles emphasizes the key importance of the so-called "unwritten doctrines" (dogmata agrapha), while indicating that clear allusions to these doctrines can be found in the dialogues; for example Republic, VI, $508 \mathrm{e} 1-509 \mathrm{c} 2$. 
abstraction") and thus maintain the thesis that mental cognition is none other than abstraction. By doing so, however, we lose a fairly important aspect. What is going on? The term "abstraction" suggests that all theses at the level of noesis are nothing more than "abstractions" from what is grasped at the level of aisthesis. Such an understanding of noesis, however, would not overcome sophistic relativism, because "abstraction" would only relate to what was captured sensually in a relative (and relational) way. In turn, "idealization" introduces a new instrument to human cognition, independent of the results of sensual perception. The possibility of creating alternative worlds in itself points to this independence. In other words, "idealization" allows for the creation of noetic models independent of aisthesis, which for Plato are to serve as an instrument for understanding reality.

At this point I will venture the thesis that Plato's defense of being - truth against sophistic arguments boils down to the procedure of reinterpreting Eleatism through Pythagoreanism. Pythagoreanism is interpreted by Plato in the context of the theory of ideas and theory of principles, which we also find in Pythagorean reflection. To put it simply, the sphere of being-truth is mathematics, which enables us to create alternative worlds in the form of axiomatic models. The problem that appears in the context of the Platonic method understood in this way concerns (analogously to the problem of the relationship between being - truth and non-being - opinions in Parmenides) the relationship between the axiomatic model (the alternative world) and the level of reality perceived by way of the senses. An attempt at resolving this difficulty will be presented in the third part of this text, devoted to the model of political epistemology.

I would like to focus on one more difficulty related to sophistry, namely the problem of utilitarianism. In light of the Apology of Protagoras, it seems that usefulness is not subject to the anthropos metron principle. A doctor or sophist recognizes what is more useful in a given context and can change the current state of affairs (related to the body's or soul's state of health) to a better, more useful one. The thing is, their job is merely to recognize, not to create something using their mind ${ }^{27}$ Recognition is about grasping how things are, and grasping how things are is grasping the truth. If usefulness was subject to the anthropos metron principle, all states and all opinions would be equally useful if only the subject of these opinions believed them to be such. However, Protagoras distinguishes between more and less useful, better and worse opinions. What is the criterion for making such a distinction? It seems that the only criterion we can indicate is the nature of things, i.e. the truth. Even if what is useful depends on the con-

27 Plato: Theaetetus, 167a2-3, b3-4. 
text, then, if in a given context something is more useful and something less useful, the only justification for this state of affairs is nature-being-truth. The only way to avoid this aporia would be to reject what is useful and recognize that all opinions and states are completely equal. This would consequently lead to the rejection of all wisdom, whether defined by truth or by usefulness. Rejecting all wisdom would render any discussion senseless, regardless of whether it concerned individual issues (individual choices and decisions), or socio-political and legal issues connected with state, political, and legal choices and decisions.

However, even in situations in which we agree that usefulness requires truth as a criterion, do we have to accept absolute and certain truth? Wouldn't it be enough to admit that since there is only non-being, then the only truth available to man is probable truth? The problem seems to lie in the fact that the graduated probability of opinions in the sphere of non-being in Parmenides's philosophy is conditioned by the certainty and necessity of the absolute truth of the sphere of existence, regardless of whether these spheres are isolated or not isolated. In other words, graduating probability does not make sense if we do not accept certainty, regardless of whether this certainty is attainable for us or not; this is analogous to the problem of similarity and identity - identity is the criterion for the graduation of similarity.

\section{The myth of the cave and Plato's model of political epistemology}

I would like to make Book VII of the Republic, i.e. the Myth (or Allegory) of the Cave, the starting point for my analysis of the Platonic model of political epistemology. ${ }^{28}$ There is no doubt that the Myth of the

28 I must point out two things. First of all, I will not take a position here on the problem of whether the description of the cave is a myth or an allegory. To accomplish the goal I have set for myself in this article, I read the cave's description in general terms; I do not devote space to analyzing every detail, which is why resolving the myth-allegory problem is not of utmost importance to me. Secondly, the vastness of literature devoted to Plato's cave and the accompanying variety of interpretations make it impossible to subject them to analysis here. I will only indicate selected items that refer to the myth of the cave: J. AnNAS: An Introduction to Plato's "Republic." Oxford 1981; J. AnNAs: 
Cave is a Platonic interpretation of Parmenides's philosophy: the reality inside the cave corresponds to the level of non-being-opinion, while the reality outside the cave corresponds to the level of being - truth. Capturing the essence of the Myth of the Cave is, in my opinion, decisive for understanding Plato's political philosophy.

What is crucial to interpreting Plato is recognizing that these two levels/spheres are not isolated from one another. In my opinion, this is not so much about the possibility of moving between the spheres - the possibility of leaving the cave and returning to it - as it is about the relationship between the epistemological models proper to both of these spheres. The mere fact of being able to move could easily be reconciled with the separation of the spheres of being and non-being. We can go from one to the other, but each time we have to adapt to the rules - the separate rules that govern each of them. In other words, what is known at the noetic level in no way makes it easier for us to understand what is found at the aisthetic level. In this way, despite the fact that we can move on both levels/spheres, both levels/spheres remain cognitively isolated from each other. Even if it could be shown that the sphere of being-truth is available to us, if knowledge of it does not translate into understanding the sphere of non-being-opinion, all the effort would, in fact, be wasted. Within the cave we would have to forget about what is outside of it. We would be forced to move around in the sophistic "darkness of non-being." Therefore, Plato's goal is not merely to rehabilitate the pre-sophistic category of absolute truth - it also concerns the socio-political consequences of absolute truth. To achieve this goal, Plato must not only rehabilitate absolute truth, but also demonstrate that it somehow conditions probabilistic cognition at the level of the cave. It does so in an intricate, vague, seemingly incoherent manner.

Plato, Republic V-VII. In: Philosophers Ancient and Modern. Ed. G. VeSEY. Cambridge 1986, pp. 3-18; S. Benardete: Socrates' Second Sailing. Chicago 1989; A. Bloom: The Republic of Plato. Trans. with an interpretative essay. New York 1968; M.F. BuRnyeat: Culture and Society in Plato's "Republic," "The Tanner Lectures on Human Values" 1999, vol. 20, pp. 215-324; T.F. Morris: Plato's Cave. "South African Journal of Philosophy" 2009, vol. 28 (4), pp. 415-432; T.F. Morris: The Way Out of Plato's Cave. "Scholia" 2008, vol. 17, pp. 2-18; A. OphiR: Plato's Invisible Cities. Discourse and the Power in the "Republic." London 1991; M.L. McPherran, Ed.: Plato's "Republic." A Critical Guide. Cambridge 2010; L. Purshouse: Plato's "Republic." London-New York 2006; D. CaIrns et al., Eds.: Pursuing the Good. Ethics and Metaphysics in Plato's "Republic." Edinburgh, 2007; C.D.C. ReEve: Philosopher-Kings. The Argument of Plato's "Republic." Indianapolis 2006; G. Santas: Understanding Plato's "Republic." Malden-Oxford-Chichester 2010; G. SAntas, Ed.: The Blackwell Guide to Plato's "Republic." Malden-Oxford-Carlton 2006; G.R.F. Ferrari, Ed.: The Cambridge Companion to Plato's "Republic." Cambridge 2007; D. Zygmuntowicz: Praktyka polityczna. Od „Państwa” do „Praw” Platona. Toruń 2011. 
In Neoplatonic sources we find a story about Pythagoras sitting by the setting sun at the entrance to the basement, which he had ordered to build for himself. ${ }^{29}$ Sitting with his face facing inside the basement, he watched the shadows moving on its wall cast by the setting sun. This story was supposed to inspire Plato to create the Myth of the Cave. However, both versions differ significantly. In the Pythagoras version we have one light source (the sun), and the shadows in the basement are a reflection of "real" patterns from outside the basement. The interpretation of this version is simple: aisthetic entities (Parmenides's non-being) are only a shadow of a noetic being (Parmenides's being). Understanding what a shadow is requires understanding what that shadow is a reflection of.

Plato's version is much more complicated. First of all, there are two sources of light - the sun and the fire. While the sun is clearly identified by Plato himself as the Good (the idea of the Good) and indirectly as the One, the answer to what fire is is extremely difficult, because Plato does not write about it directly. He merely mentions that this fire somehow comes from the $\operatorname{Good}^{30}$ and compares it to the sun. And the solution to this puzzle seems extremely important, because it is the light of the fire, not the sun, ${ }^{31}$ that creates shadows on the cave wall.

Secondly, the shadows in the cave are reflections of the products carried over the wall, not the "real" patterns outside the cave. The items carried over the wall, in turn, are merely "reflections" of these "real" patterns. As a consequence, we have a rather unclear situation. The ultimate goal is the best possible organization of life in the cave (i.e. socio-political life), for which the necessary tool is to recognize what the shadows are. The shadows are a reflection of the items carried over the wall. And essentially, to understand what appears in the cave in the form of shadows, it would suffice to get to know the items carried over the wall. What does the knowledge of a giraffe contribute to recognizing and understanding the shadow of a giraffe sculpture? Is it not enough to know about the giraffe sculpture itself? To answer these questions, it is first necessary to understand whether there are items carried over the wall, and who are those who carry them.

At the starting point, therefore, we have two basic problems: 1) what is the fire, and 2) what are the items carried over the wall and who are they carried by. It is all reduced to understanding the level of the fire, the path, and the wall. The difficulty is increased by the fact that Plato's description does not clearly show whether this "mysterious trinity" is inside the cave, outside the cave, or at the very entrance to the cave. In other words: do the

29 Porphyry: Vita Pythagorae, 9, 5-8.

30 Plato: Republic, VII, 517c3.

31 Plato: Republic, VII, 517b3-4. 
fire, the path, and the wall belong to the aisthetic level, the noetic level, or do they designate a separate, intermediate third level of veritative being and cognition?

Being aware that all these issues are extremely complicated and unclear, and that resolving them (if at all possible) goes far beyond the scope of this publication, I will accept two working hypotheses and test what consequences follow.

The first hypothesis concerns the status of the level between the fire and the wall. I assume that this is an intermediate level, between the cave (whether the cave represents aisthesis is an open matter for now) and the noetic level.

Secondly, keeping to the veritative context consistently maintained in this article, I assume that the whole Myth of the Cave illustrates our cognitive capabilities, our ways of building "truth." Each level shown in the myth will correspond to its own level of reason (mind) and the level of veritative being associated with it.

I will analyze both hypotheses together, because they are inextricably linked. However, let us first conduct a small intellectual experiment. Imagine a cave in which the wall separating it from the path and fire reaches the ceiling itself. The cave is completely dark, not a single photon or phonon reaches it. Speaking anachronistically, we would then be dealing with the purest form of Cogito - it would be a mind alone with itself, devoid of any sensory data. Using Plato's language, a closed cave would be a soul in a state of memory loss, devoid of the sensory impressions that would allow it to recall what has been forgotten. Such a soul would not be able to "give birth to" any knowledge, would not be able to remember anything. ${ }^{32}$ However, the cave is not closed - its entrance are the senses that make anamnesis possible for the soul. Sensory impressions are symbolized by shadows and echo. It is on their basis that the human mind constructs an interpretation of reality - from eikasia to pistis. The stage of climbing uphill towards the fire begins. What is the level between the wall and fire? Let us put forth another hypothesis - this level represents abstract thinking, an intermediate stage between the cave and noetic thinking. Though this stage is dependent on aisthesis, it is here that the possibility of going beyond aisthesis is revealed. This is the level of dianoia, for which the level of mathematical entities becomes crucial. As I have indicated above, among the mathematical entities, geometric-stereometric entities that result from idealization have a special status - they lead beyond the fire, to noetic thinking, which is completely free of sensory impressions.

\footnotetext{
32 Plato: Phaedo, 75e2-76a7.
} 
To sum up, let us reconstruct the Myth of the Cave from the perspective of the two hypotheses:

1. The cave itself symbolizes the soul, the state of memory loss and immersion in the darkness of ignorance. The firelight reaching the cave enables anamnesis (a closed cave would be a state of permanent darkness and oblivion, without any understanding, whether at the level of episteme or of doxa). All human cognition necessarily begins with sensory impressions.

2. The level between the fire and the wall is the level of abstract cognition - dianoia. This knowledge is higher than eikasia and pistis, but still based on sensory cognition. It is at this level that the mind generalizes, recognizes physical laws, etc.; at the same time, thanks to idealization (geometry and stereometry), the seeds of noetic cognition are formed at this level. What is the fire? In my opinion, it would be best to identify it with the principle of sensual cognition in the broadest sense. ${ }^{33}$ How should this level of cognition be classified within the context of Parmenides's thought? This question requires a slightly longer answer and reference to Pythagorean philosophy.

As I suggested above in comparing Parmenides with the Pythagoreans, mathematics in Pythagorean thought would correspond to the level of being - truth. An illustration of this would be the description of Pythagoras's basement cited by the Neoplatonists: what is inside the basement is reality perceived sensually, what is outside that basement - is the level of mathematics. The problem lies in the relationship between these levels, or more precisely — in their epistemological — veritative relationship. We are familiar with Plato's criticism of the method of determining a mathematical interpretation of music. According to many researchers, this is a criticism of the Pythagorean method. ${ }^{34}$ In my opinion, the issue is open, but for the purpose of these reflections I will accept this interpretation. What is the essence of this criticism? According to Plato, although the Pythagorean method discovered the mathematical possibility of expressing aisthetic reality (i.e. it discovered the interaction between being - truth and non-beingopinions), it seems to have stopped halfway: it is attempting to extract mathematical dependencies from the empirical study of aisthesis, instead of what Plato believed would be more fruitful — imposing these mathematical

33 Regarding the criticism of interpretations that see in the cave itself a level of various possible misrepresentations of reality, see: T.F. Morris: Plato's Cave, pp. 415-432. I strongly agree with the author's argument.

34 Plato: Republic, VII, 531b2-c4. Regarding the identification of Plato's criticism with criticism of the Pythagorean method, see e.g. C.A. Huffman: Archytas. Music and Mathematics. In: Stanford Encyclopedia of Philosophy, https://plato.stanford.edu/entries/ archytas/. 
dependencies on aisthesis. In other words - Plato seems to suggest building a mathematical model first, to which data from aisthesis should then be adapted. The ability to build a mathematical model, however, requires higher justification - higher in an epistemological and veritative sense. Such justification can only come through the consistent application of idealization, which is abstraction from abstraction, release from all sensory data, i.e. a transition to the noetic level.

Consequently, the status of the intermediate level depends on the possibility of going beyond the fire. If we do not allow for this possibility, then the intermediate level should be included in the level of non-being-opinions. In turn, if we do allow for this possibility, the status of the intermediate level changes - it becomes the lowest level of being - truth. Ultimately, everything depends on the legitimacy of mathematical instruments. If the rules of mathematics are "extracted" from the aisthetic level and thus justified by that level, we are dealing with non-being-opinion. If, in turn, mathematical rules are a model imposed on the aisthetic level and justified noetically, their status is higher - they belong to the level of being - truth.

Let us now apply the above analyses to Plato's political reflection. Let us take a look at the issue of justice; after all, it is the main (or at least explicitly indicated as such within the dialogue) subject of Plato's analysis in the Republic.

At the starting point, let us reconstruct the path leading to the establishment of the principles of justice from a sophistic perspective. At its base lies the assumption that all people have a (innate?) sense of law (dike) and shame (aidos). ${ }^{35}$ However, what justice is, what its principles and its content should be, are all subject to the anthropos metron principle. The diversity of equally strong opinions - in terms of their degree of truthfulness - makes determining the rules of justice an extremely complicated task. The solution to the problem seems to be the reference to democratic procedures, that is, making decisions by a majority vote. However, this is only a procedural solution. It does not guarantee that the result obtained will be the best, or even satisfactory. Herein lies the most important difficulty - does it even make sense in the context of anthropos metron to undertake the question of what is "best," "better," or "good"? Usefulness seems to be Protagoras's answer - if a certain state or opinion leads to greater functionality than another state or opinion, the more functional solution should be chosen. The more useful thus becomes the more just. However, this means that usefulness is not subject to the anthropos metron

35 Plato: Protagoras, 322c1-d5. 
principle. ${ }^{36}$ While all opinions are equivalent in terms of truthfulness, they are not equivalent in terms of their usefulness. Let us illustrate the above statement with the Myth of the Cave: at the level of the cave, opinions are equal in terms of truth, but the same opinions are subject to hierarchization at a higher level - the level between the fire and the wall. Why do I put forth the thesis that usefulness and justice in sophistic thought belong to this level and not to the level of the cave? Because they correspond to a different state of mind, a different method of reflection. This is not the simple organization of sensual impressions and the opinions constructed on their basis. This is an attempt at discovering certain principles. However, these lack higher justification; they are still rooted in the "shadows" of the cave. And this is what Plato criticizes.

From the perspective of Plato's epistemology, the correct path of discourse on justice must go from abstraction to idealization. Sophists stop at the pragmatic stage, at establishing only the practical aspect of justice. According to Plato, the discussion on justice requires determining what justice is in itself and what justifies it. In other words, the thesis that what is most useful is just (leaving aside the problem of the criterion of what is useful for now), which results from observations and their analyses, becomes an unfounded judgment, if it is not justified by something other than what justice is supposed to regulate.

In Book VI of the Republic, Plato points to the Good (the idea of the Good) as the ultimate justification of justice. ${ }^{37}$ The main task of justice is to maintain the Good in the structure of the poleis. But what is the Platonic Good? It is identical to the highest, first, and final justification of all knowledge and all being - the One. The One - the Good, which in the Myth of the Cave is symbolized by the sun, on the one hand completes the whole process of idealization, and on the other, it is a prerequisite for all knowledge. It justifies the truth of noetic cognition, and also grants probability to the cognition and understanding of the sphere of non-being.

Consequently, Plato's thesis becomes clear that only philosophers, i.e. those who have gained understanding of the One- the Good, should direct political and legal affairs. ${ }^{38}$ Only those who have a non-contradictory explanatory model independent of sensory data have knowledge not only of how things are, but also of why they are this way. The sophists' conception is limited only to the first level - to the level of knowledge of craftsmen, using Aristotle's terminology. ${ }^{39}$ Returning to the example of the giraffe

\footnotetext{
36 Plato: Theaetetus, 167b2-4.

37 Plato: Republic, VI, 504b1-505b3.

38 Plato: Republic, VII, 520c1-6.

39 Aristotle: Metaphysics, I, 1, 981a24-b6.
} 
sculpture: knowledge of a giraffe will allow for a more adequate interpretation of the giraffe sculpture, and as a consequence also a more adequate interpretation of the shadow (shadows) of that sculpture. If the sculpture of a giraffe were to be the final justification, then relativism would be impossible to overcome.

Knowledge at the noetic level, as a particular axiomatic model, however, is not knowledge of a "material" nature, but only of a "formal" nature. There are no absolute, non-relative contents of justice whose application (implementation) will be best in all circumstances. The noetic axiomatic model is sensitive to the context, to the specifics of the "material" that it is to "form." ${ }^{40}$ Consequently, it is impossible to formulate an absolute and simultaneously "material" model of justice. Without reference to the noetic level as a necessary condition for human cognition, the only remaining option would be to follow the path indicated by sophistry. Plato seems to agree with the sophists that in relation to the "material," "content-based" aspect, we are necessarily entangled in relativism. That is why he moves the discussion to the noetic level - by entering the field of discussion on noetic axiomatic models, we are able to overcome the relativism of aisthetic cognition. This is of great importance for political reflection. Just as understanding the cube model frees us from the relativism of sensual impressions and the equally-true-not-true opinions built on the basis of those impressions, so understanding the model of justice justified by the One-the Good liberates us from the relativism of equally-true-not-true opinions about justice.

Plato's political epistemology is composed of three levels. The highest level is political noesis, in which the most important aspects are pure reflection on the good and on justice. The lowest level is the level of the cave, the level of individual relative impressions and opinions. The intermediate level is political reality in the strict sense - this includes, first and foremost, constitutional law and the political decision-making process. The intermediate status of this level is not only due to the fact that it is depicted "between" the cave and the path to the sun in the Myth of the Cave. It is an intermediate level because it indeed "mediates" between the two extreme levels. It "mediates" in both a veritative-epistemological and a practical sense. It is at this level, according to Plato, that "mediation" should be undertaken between empirical data and individual opinions, and the noetic model. The outcome achieved as a result of such "mediation," of "matching up" these extreme levels, should indeed harmonize them. This harmonization on veritative-epistemic grounds means compatibility with

\footnotetext{
40 Similarly: Aristotle: Politics, 1288b10-1289a25.
} 
the cave and with noesis. On practical grounds, in turn, practicality is expressed in greater usefulness, which is lacking both at the level of the cave (due to relativism) and at the level of noesis (due to the "formal" nature of noetic knowledge).

\section{Conclusion}

In conclusion, I would like to refer once again to one of the issues raised above, namely to interpreting the Myth of the Cave in the context of Parmenides's of Elea thought, i.e. the dualism of being - truth and nonbeing-opinions. The doubts concern the classification of the intermediate level. I suggested above that the status of this level depends on the type of justification: if the justification is the cave, then the level should be classified as non-being-opinion, if the justification is noesis, then the level should be classified as being - truth. Such reasoning can be criticized by indicating that no findings at the intermediate level will ever obtain the status of certainty and necessity that characterizes being-truth. These findings will always be probable, and this is characteristic of the level of non-being-opinions. Perhaps it would be reasonable to consider the level between the wall and the fire as a separate, indeed intermediate, veritativeepistemological level, simultaneously indicating that Plato's conception simply cannot be reconciled with Parmenides's conception.

Though aware of these difficulties, I am inclined to agree with the position described earlier because of the problem of justification. It is the only way in which you can distinguish the sophists' method from that of Plato. The sophistic approach to political issues can be classified as belonging completely to the level of non-being-opinions. If we classified Plato's political practice, which is justified by a noetic model, in the same way, it would mean disregarding significant, even key differences between the two methods. Even if in certain circumstances, in the "material" aspect, Plato and the sophists would agree on the same proposal of understanding justice (or rather, on the same proposal of legal solutions), the differences in justification would be diametrically different: for sophists, it would lie in the usefulness of opinions and experience, for Plato - in the coherence and clarity of the noetic model. Sooner or later, such a difference in justification must also lead to significant "material" differences. 


\section{Bibliography}

De Melisso, Xenophane, Gorgia. In: Aristotelis De Melliso, Xenophaneet Gorgia disputations cum Eleaticorum Philosophorum fragmentis. Ed. F.W.A. Mullach. Berlin 1845.

Aristotle: Metaphysics. Ed. W. JAeger. Oxford 1957.

Aristotle: Politics. Ed. W.D. Ross. Oxford 1957.

Plato: Cratylus. In: Platonis Opera. Vol. I. Ed. J. Burnet. Oxford 1955-1957.

Plato: Phaedo. In: Platonis Opera. Vol. I. Ed. J. Burnet. Oxford 1955-1957.

Plato: Protagoras. In: Platonis Opera. Vol. III. Ed. J. Burnet. Oxford 1955-1957. Plato: Republic. In: Platonis Opera. Vol. IV. Ed. J. Burnet. Oxford 1955-1957.

Plato: Theaetetus. In: Platonis Opera. Vol. I. Ed. J. Burnet. Oxford 1955-1957. Porphyry: Vita Pythagorae. In: Des Places É. Segonds A.-Ph. Porphyre. Vie de Pythagore. Lettre a Marcella. Paris 1982.

Sextus Empiricus: Adversus Mathematicos. Eds. H. Mutschmann, J. Mau. Leipzig 1914-1954.

Sextus Empiricus: Pyrrhoniae hypotyposes. In: Sexti Empirici Opera. Vol. I. Ed. H. Mutschmann, J. Mau. Leipzig 1958.

Annas J.: An Introduction to Plato's “Republic.” Oxford 1981.

Annas J.: Plato, Republic V-VII. In: Philosophers Ancient and Modern. Ed. G. Vesey, pp. 3-18. Cambridge 1986.

Benardete S.: Socrates' Second Sailing. Chicago 1989.

Bloom A.: The Republic of Plato. Trans. with an interpretative essay. New York 1968.

Burnyeat M.F.: Culture and Society in Plato's "Republic." "The Tanner Lectures on Human Values" 1999, vol. 20, pp. 215-324

Cairns D. et al. Ed.: Pursuing the Good. Ethics and Metaphysics in Plato's "Republic." Edinburgh 2007.

Calogero G.: Studi sull' Eleatismo. Roma 1932.

CASsin B.: Si Parmenide. Le traite anonyme De Melisso Xenophane Gorgia. Edition critique et commentaire. Lille 1980.

Ferrari G.R.F. Ed.: The Cambridge Companion to Plato's "Republic.” Cambridge 2007.

GAINES R.N.: Knowledge and Discourse in Gorgias's "On the Non-Existent or On Nature," "Philosophy and Rhetoric" 1997, vol. 30, no. 1, pp. 1-12.

Gajda-Krynicka J.: Sofiści. Warszawa 1989.

GaJdA-Krynicka J.: Przedplatońskie koncepcje prawdy. Gorgiasz z Leontinoi. In: Prawda, język, szczęście. Studia z filozofii starożytnej (II). Eds. J. GAJDA, A. Orzechowski, D. Dembińska-Siury. Wrocław 1992, pp. 15-54.

Gigon O.: Gorgias „Uber das Nichtsein.” “Hermes” 1936, vol. 71, pp. 186-213.

Gomperz H.: Sophistik und Rhetorik. Leipzig 1912. 
Huffman C.A.: Archytas. Music and Mathematics. In: Stanford Encyclopedia of Philosophy, https://plato.stanford.edu/entries/archytas/

KaHn C.H.: The Greek Verb "To Be" and the Concept of Being. "Foundations of Language" 1966, vol. 2, pp. 245-265.

Kerferd G.B.: The First Greek Sophists. "The Classical Review" 1950, vol. 64/1 (Apr.), pp. 8-10.

Kerferd G.B.: The Sophistic Movement. Cambridge 1981.

Kerferd G.B. Ed.: The Sophists and Their Legacy (Hermes Einzelschriften, 44), Wiesbaden 1981.

Kubok D.: Prawda i mniemania. Studium filozofii Parmenidesa z Elei. Katowice 2004.

Levi A.: The Ethical and Social Thought of Protagoras. "Mind" 1940, vol. 40, pp. 284-302.

Long A.: Refutation and Relativism in Theaetetus 161-171. "Phronesis" 2003, vol. XLIX/1, pp. 24-40.

McPherran M.L. Ed.: Plato's "Republic." A Critical Guide. Cambridge 2010.

Mendelson M.: Many Sides: A Protagorean Approach to the Theory, Practice and Pedagogy of Argument. Dordrecht—Boston-London 2002.

Mor RIs T.F.: Plato's Cave. "South African Journal of Philosophy" 2009, vol. 28(4), pp. $415-432$.

Morris T.F.: The Way Out of Plato's Cave. "Scholia" 2008, vol. 17, pp. 2-18.

Nerczuk Z.: Sztuka a prawda. Problem sztuki w dyskusji między Gorgiaszem a Platonem. Wrocław 2002.

Nerczuk Z.: Miara jest każdy z nas. Projekt zwolenników zmienności rzeczy w platońskim Teajtecie na tle myśli sofistycznej. Toruń 2009.

Nerczuk Z.: Parafraza gorgiańskiego traktatu „O niebycie” $w$ wersji Sekstusa Empiryka. In: Sapereaude. Księga pamiatkowa ofiarowana profesorowi dr. hab. Marianowi Szarmachowi z okazji 65 rocznicy urodzin. Ed. I. MıкоŁAJCZYK. Toruń 2004, pp. 185-201.

Nerczuk Z.: Traktat „O niebycie” Gorgiasza z Leontinoi. "Przegląd Filozoficzny - Nowa Seria" 1997, vol. 3, no. 23, pp. 79-94.

NerczuK Z.: Wokót sofistyki. Torun 2016.

Nussbaum M.: Sophistry about Conventions. "New Literary History" 1985, vol. 17, no. 1, Philosophy of Science and Literary Theory, pp. 129-139.

Ophir A.: Plato's Invisible Cities. Discourse and the Power in the "Republic." London 1991.

Purshouse L.: Plato's “Republic.” London-New York 2006.

Reeve C.D.C.: Philosopher-Kings. The Argument of Plato's "Republic." Indianapolis 2006.

Santas G. Ed.: The Blackwell Guide to Plato's “Republic." Malden-OxfordCarlton 2006.

Santas G.: Understanding Plato's "Republic." Malden-Oxford-Chichester 2010.

Schiappa E.: Interpreting Gorgias's "Being" in "On Not-Being or On Nature." "Philosophy and Rhetoric" 1997, vol. 30, no. 1, pp. 13-30. 
Schiappa E.: Protagoras and Logos: A Study in Greek Philosophy and Rhetoric. Columbia (South Carolina) 2003.

Walters F.D.: Gorgias as Philosopher of Being: Epistemic Foundationalism in Sophistic Thought. "Philosophy and Rhetoric" 1994, vol. 27, no. 2, pp. 143-155. Zygmuntowicz D.: Praktyka polityczna. Od „Państwa” do „Praw” Platona. Toruń 2011.

Piotr Świercz — doktor habilitowany, profesor na Wydziale Filozoficznym Akademii Ignatianum w Krakowie. 